\title{
Publisher Correction: Mitigation potential of global ammonia emissions and related health impacts in the trade network
}

\author{
Rong Ma, Ke Li (i), Yixin Guo (1), Bo Zhang, Xueli Zhao, Soeren Linder, ChengHe Guan, Guoqian Chen (1), \\ Yujie Gan \& Jing Meng (D)
}

Correction to: Nature Communications https://doi.org/10.1038/s41467-021-25854-3, published online 5 November 2021.

In this article the affiliation details for Guoqian Chen were incorrectly given as 'Laboratory of Systems Ecology and Sustainability Science, College of EngineeS-Chem model code is open-souring, Peking University, Beijing, China' but should have been 'Laboratory of Systems Ecology and Sustainability Science, College of Engineering, Peking University, Beijing, China'. The original article has been corrected.

Published online: 30 November 2021

\footnotetext{
(c) (i) Open Access This article is licensed under a Creative Commons Attribution 4.0 International License, which permits use, sharing, adaptation, distribution and reproduction in any medium or format, as long as you give appropriate credit to the original author(s) and the source, provide a link to the Creative Commons license, and indicate if changes were made. The images or other third party material in this article are included in the article's Creative Commons license, unless indicated otherwise in a credit line to the material. If material is not included in the article's Creative Commons license and your intended use is not permitted by statutory regulation or exceeds the permitted use, you will need to obtain permission directly from the copyright holder. To view a copy of this license, visit http://creativecommons.org/licenses/by/4.0/.
}

() The Author(s) 2021 